\title{
FACTORS CONTRIBUTING TO DOMESTIC VIOLENCE
}

\author{
Marcela Tittlová \\ Institute of Public Law, Faculty of Law, Pan-European University \\ Bratislava, Slovak Republic \\ marcela.tittlova@paneurouni.com

\section{Peter Papáček} \\ Institute of Public Law, Faculty of Law, Pan-European University \\ Bratislava, Slovak Republic \\ peter.papacek@gmail.com
}

\begin{abstract}
The search for possible solutions and tools to fight domestic violence always ends up with searching for the causes of this negative phenomenon. To answer what causes domestic violence turns out as a challenging issue. Knowing the causes of domestic violence could be the key to the elimination of domestic violence from our society. Etiology is a partial component of criminology that focuses on the discovery and investigation of the causes of criminal behavior in individuals. Knowing the causes of crime as such is in itself a very demanding process. The cause creates a casual relationship between phenomena which are unchangeable. The causes of violent behavior in domestic violence have never been accurately and unequivocally proven. For this reason, it is more appropriate to identify and investigate criminogenic factors of criminal behavior. These are factors, which in themselves, or in a combination of them, support, enable, incite, facilitate the emergence or development of criminal behavior.
\end{abstract}

KEYWORDS: domestic, violence, behavior, etiology, reasons

JEL CLASSIFICATION: K10, K14, K38

DOI: $10.2478 /$ IJEK-2018-0019

Received: $29^{\text {th }}$ November, 2018

$1^{\text {st }}$ Revision: $15^{\text {th }}$ December, 2018

Accepted: $28^{\text {th }}$ December, 2018

Reference: Tittlova, M., Papáček, P. (2018). Factors Contributing To Domestic Violence. International Journal of Entrepreneurial Knowledge, 6(2), 117-124. doi: 10.2478/IJEK-2018-0019

\section{INTRODUCTION}

As we mentioned in the abstract, the search for possible solutions and tools to fight domestic violence always ends up with searching for the causes of this negative phenomenon. Why is there domestic violence at all? Why do certain groups of the population (either women, children, men or seniors, etc.) become victims of domestic violence and on the other hand, what makes the aggressor to behave violent? Why are some entities in the same group of population becoming victims of domestic violence and other entities from the same group under the same conditions not? Maybe the answers seem to be simple at first glance, but in fact it is a challenging issue. Knowing the causes of domestic violence is seen in the current available literature as the knowledge of its roots. The removal of its causes is being compared to the elimination of domestic violence from our society. Many researches are devoted to the knowledge of domestic violence, that is to its partial questions. However, there are fewer researches that have focused on identifying and investigating the causes of domestic violence in individual groups of the population. Most frequently these studies are focused on detecting and studying the causes of domestic violence on women and children. Only a minimum of studies are examining the causes of domestic violence on seniors or on disabled people. Researches examining the causes of domestic violence on men we can only meet very rarely, even though they are one of the possible group of 
victims of domestic violence. With development itself, emancipation and the consistent promotion of human rights we are increasingly confronted with families in which women have the dominant position. They are abusing their position in certain ways and they are getting into the position of the aggressors towards their partners or husbands. Studies of the causes of the above mentioned behavior as violence against men are unfortunately still absenting in our country. Clearly from these facts it is seen that even in this very frequently studied area, there are some partial aspects that have not been sufficiently examined and described yet (Tittlová, 2017).

\section{CAUSE OR THE RISK FACTOR}

Regarding to the causes of domestic violence, as Holcr (2008) writes it is necessary to clarify the fact that their knowledge is extremely demanding or even impossible. For that reason, the most of criminologists tend to identify criminogenic factors as the risk factors of domestic violence or violent behavior in the family in general. As we have already mentioned, the key is to answer the question why does domestic violence occur at all and why do certain entities from different groups of population become victims of this phenomenon and others not. It is often possible to completely compare the living and subsistence conditions of all subjects and it is interesting that some of them become victims of domestic violence and others exactly in the same conditions do not. Therefore, it is not possible to clearly state that the cause of domestic violence is one or the other phenomenon. Consideration is given only to certain risk factors where the possibility of violent behavior is increasing. It may appear, but not necessarily occur in every case. There is a high number of internal and external factors, affecting the emergence of domestic violence, while the development and the course of many of them can not be accurately described in any way. Interestingly, besides the external factors, on the rise of violent behavior in families even internal factors are significantly participating. These factors are generally investigated on the side of the aggressor, but the behavior of the victims may contribute to their own victimization, though without their knowledge or intention (Cabanova, 2006). It is important to be aware of the constant features of domestic violence against other types or forms of crime. In the case of domestic violence, two life paths are confronted, which are connected with relatively deep bounds. Both subjects - the victim and the aggressor - naturally grew up in a family environment that influenced and shaped them in a certain way. Similarly, both of these entities form together a family or another very close community, which greatly affects its members and forms their personalities. Last, but not least, cohabitation in families also affects other subjects, so the behavior of the victim and the aggressor, and individual attacks in the context of domestic violence also affects them, naturally in a negative way.

In the criminal procedure point of view, domestic violence in case of grievous bodily injury is a reason for issuing the European arrest warrant (Klimek, 2012), even the requested person would not accept it (Klimek, 2014).

\section{THE DIVISION OF THE RISK FACTORS}

Among the different criteria for categorizing the risk factors of domestic violence, we found the most appropriate to break them down into these factors:

- Individual factors, that is relating to an individual,

- Factors rooted in the idea of society - social factors,

- Factors depending on the nature, character and linkage that arises in a relationship (also known as factors of relationships),

- Factors operating in a certain closed environment in which domestic violence subjects live - so called factors of kinship community. 
All of these categories include a variety of factors that can be economic, financial, material, social or related in their nature. Nowadays, the social, financial and material factors undoubtedly can be considered as highly risky in the society. These mentioned factors often have the effect of creating an environment in which domestic violence will break out or it will escalate. The social situation, the financial circumstances or the economic situation of families are, according to international organizations, one of the most risky factors not only of domestic violence, but of criminal behavior in general. $^{3}$

It is possible to subsume a whole range of factors under the above mentioned groups of risk factors which in families do not usually act independently, but in various combinations. The increasing number of mutually combining risk factors naturally weakens each of them, but on the other hand, increases the probability of violent behavior. The following risk factors can be subsumed under different groups:

- Individual factors (relating to an individual)

- Low age, that is the partners' youth which is associated with the level of their personal maturity, physical and psychological predispositions; opportunities to become parents and to function in this role,

- Excessive alcohol consumption of one of the partners,

- Usage of some other narcotics by one of the partners,

- Mental illness, disorders, serious depressive states,

- Strong temperament, emotional lability, affectivity,

- Any or only basic or vocational education,

- Financially poorly ranked job classification of low income in general,

- Dispositions of domestic violence which are encoded in individuals from their original family environment (usually when they were directly exposed to domestic violence or they were witnesses of domestic violence as children).

- Factors rooted in the idea of our society - so called social factors

- In society there is a family arrangement where the man represents the head of the family and he is its guardian and leader,

- Hierarchy of relationships between a woman and a man in which woman has a subordinate, inferior and less-ranked position,

- Social perception of a woman solely as a wife and a mother with which the care of the household, the man, the births of the babies and their upbringing is connected,

- The existence of norms that help the survival of violence in society (different sayings in which domestic violence often occurs).

- Factors based on the nature, character and linkage that can arise in a relationship (so called relationship factors)

- Quarrels and conflicts in partnerships, parent-children relationships or the one between children, grandparents, etc.,

- Incompleteness of families,

- Pathological and criminal behaviors in families,

- Instability in relationships,

- Excessive male dominance,

- Preference for one of the offspring,

- Social weakness of families, poverty,

- Economic imbalance.

- Factors operating in a certain environment in which the subjects of domestic violence live (so called factors of community, collective or environment)

\footnotetext{
${ }^{3}$ World Health Organization: World Report on Violence and Health. Geneva, 2002, s. 98
} 
- The absence of legislation that deals effectively and comprehensively with the problem of domestic violence,

- Difficulties in detecting and proving domestic violence,

- Relatively low sanctions against aggressors for their violent behavior in domestic violence,

- Benevolence against domestic violence, its oversight, its alleviation, accusation of victims,

- Low social awareness,

- Weak community cohesion,

- Disinterest.

\section{THE SCOPE OF THE RISK FACTORS}

\subsection{Alcoholism as a risk factor}

Excessive consumption of alcohol or alcoholism is significantly signed under the violent behavior of individuals in general. It also significantly impinges on violent behavior in domestic violence. It helps the formation, development and escalation of domestic violence and prevents its effective solution. Alcoholism is one of the pathological manifestations in families which is directly and very closely related with domestic violence. In lots of studies it can be clearly seen that alcohol is releasing barriers, increasing aggressivity, helping to ventilate stressful situations and increasing tensions what play a very important role in domestic violence. Alcoholism itself can be perceived as a risk factor, but not in its traditional perception. A certain link between alcoholism or the usage of other narcotics and domestic violence is evident, but these addictions are much more able to exacerbate the existing problems in different forms of risk factors which are even present. According to statistical surveys, it appears that on average up to $70 \%$ of the aggressors were under the influence of alcohol or other drugs during the attacks. In conjunction with several factors, alcoholism or other addictions contribute to the outbreak or to the increase of the intensity of domestic violence. However, no research has confirmed the casual relationship between the usage of alcohol or other drugs and domestic violence. According to psychological studies, heavy alcoholics only rarely behave violently in the family. Their conduct is focused and motivated differently. Domestic violence in these cases justifies the existence of other risk factors. Although under the influence of these substances the aggressiveness of physical attacks may increase, but at the time of soberness other forms of domestic violence are present - psychical violence, sexual violence, neglect, social or economic control. This fact, on the contrary to other forms, can occur during the full awareness of the aggressor, suggests that the cause of domestic violence has its roots in other risk factor or is a combination of them, but it is not the dependence itself. It is true that violent attacks can exacerbate and can be more intensive under the influence of these substances. In case of some aggressors a thorough preparation or the planning of a violent attack was proved and the alcohol was only the trigger in these cases. According to psychologists if there were no alcohol or drug abusive attacks, they would certainly occur additionally.

Although a link between alcoholism and other addictions can not be denied, domestic violence as an abuse of dominant position is not a direct result of these pathological phenomena. More often alcoholism is being used by aggressors as an excuse to hide or justify violent attacks. It is necessary to realize that alcoholism or other addictions are currently very widespread, but only a certain percentage of people are acting violently in the family under their influence. On the other hand, violent behavior occurs in many cases even without different addictions. Alcoholism and other addictions as causes of domestic violence need to be perceived as one of the myths in the field of justification of this phenomenon.

\subsection{Factors of the violence against women}


For the causes of domestic violence against women there are several theories that try to justify this phenomenon. We meet theories that justify domestic violence by factors on the side of the individuals, they give specific explanations (different addictions, alcoholism, stress, psychological problems, etc.), but such justifications are not sufficient and neither entirely consistent. However, all of the above mentioned phenomena may be the trigger of aggressive behavior, but the risk factors which justify the domestic violence against women do not elucidate completely. Significantly more effective are structural approaches to justify domestic violence against women. These approaches emphasize that as a result of socialization, our society lives in in an environment dominated by gender stereotypes. Violence against women, which occurs in families, is thus only a reflection of the imbalance between men and women in society still remains. Naturally, the most notable imbalance could be seen in the economic, human rights or intimate sphere. These negative trends remaining with us, are the remnants of past eras in which such organization and hierarchy were strictly applied. Nowadays, these phenomena are percieved as highly negative. Women's political, social or economic dependence automatically creates a space for building a power position for male gender. This is how a space is created for the application of the old habits, traditions or arrangements that were typical for previous eras. Characteristic feature of these cases is a consistent class arrangement and gender inequality. The acceptance of gender equality between sexes in all areas of social life is the basis for eliminating violence against woman in their family. Of course, in many cases (in many cultures and areas) domestic violence against women is rooted in strict religion, majority belief. Typically, Muslim countries are considered to be those in which religions, traditions and customs promote gender inequality between men and women, that means they clearly prefer male gender. Men have there not only the monopoly of power, but also the monopoly of decision-making, material monopoly, financial monopoly and monopoly of education. In some cases, also the media contribute to the gender inequality with the formats they present. Furthermore, especially in the intimate area, the educational institutions present a traditional view of the roles of man and woman in relationship. This all contributes to the existence of gender inequality in our society, in relationships and overall in the imagination of a considerable part of the population. The dominant position, the power monopoly, the ability to make decisions about the family or about financial issues is attributed to the man which naturally leads to a certain discrimination of the female sex. These very facts alone are seen as serious interference with women's rights. This nature can be clearly admitted to violent assaults for which gender imbalance is the source and basis (Egger, 1999).

Other factors which help the emergence of violence against women in the family can be also the traditional views of male sex in itself. In addition to physical dominance a man is presented as a protector, breadwinner and a dominant subject. In the traditional role of a man, no personal failure or manifestation of personal weakness is allowed. Boys are often brought up with this from their childhood to their late puberty, while we talk about the same human beings as the opposite sex. Men also experience emotions, even though they do not show them, because it is not their biological essence. Emotions, winnings, losses and disappointments however, they live through in the same way like women do. The belief that a man must be strong, stable in decisions and successful in any case often leads to the emergence of risk factors of domestic violence. The manifestation of different forms of domestic violence are supposed to present outwardly what is expected from a man and what does he miss in particular cases. According to the results of some German surveys confirmed by Bentovin (1998), unlike the required standards for the male role in society, failure seems to be as one of the key causes of aggressive behavior in families (both against children and women). Aggressive and violent behavior is a form of self-assertion (of a man or a boy) in the social environment. Apart from that, whether if the violent behavior was encoded in a man from his childhood, this knowledge makes possible to justify the violent behavior not only against women, but also against children with any male individual. Of course, not all men behave violently, though potentially this tool of self-assertion can be used. Traditionally oriented socialization leads men to perceive themselves as the head of the family and women as mothers and wives. Different surveys have shown that all individuals using violent models of behavior have come from families and an environment in which the typical division of roles, tasks or 
positions has been applied, so the traditional perception of man and woman has not been questioned. The man finds it difficult to reconcile with the change of his dominant position in which he was brought up, in which he lived all his life and he automatically wants to regain his position. He wants to succeed (to get the position of power) in the new environment and he uses violent forms of behavior in the family for these purposes.

Available resources point to the fact that many males who behave violently in their families lived and had been brought up in an environment dominated by an extreme patriarchal structure. For men who have been raised in such system, their dominant position is absolutely natural. For such men, violence against women and children is a natural tool for ensuring obedience and proper functioning of the household. Domestic violence is a reaction to the failure of women or children to do so that it suits men's ideas. Such a rooting of violent behavior from the aspect of the appearance of domestic violence at a later time is highly risky and almost always leads to domestic violence.

\subsection{Factors of violence against children}

Domestic violence in relation to children is in many cases very similar to violence against women. It is a manifestation of the dominant and authoritarian position of a man in the family, household, etc. It is some kind of means of forced obedience and promoting man as such. As it used to be in the past, the man was deciding about the education of children, so it was the man, who decided even about the physical existence of the children a few thousand years ago. Similarly, in Rome, male offspring was promoted to the detriment of the female. Newborn girls were killed immediately after their birth because they were not beneficial to their fathers. They were associated with additional costs and so it was economically less beneficial to have a girl than a boy. The perception of this important position of a man in our society still persists. Often this traditional position is the cause of child abuse. Last, but not least, it is a tool of obedience enforcement and a child-raising tool in families, which is naturally not acceptable. Neglect as a form of violence against children is a manifestation of some kind of benevolence towards their own children, some form of abuse or education method - punishing a child. Such forms of abuse are especially used by parents (mothers and fathers alone of together) who did not want to have children or who do not have a positive relationship with children. However, the abuse of children may also be a response to their uncontrollability, the failure of parents with their education and the fact that parents are no longer able to manage children who are hyperactive or very lively. Violence against them may therefore have an educational character for the parent, but it can also be the summit of the long-term accumulated tensions and stress which are often caused by the education of children and its confounding.

\subsection{Factors of the violence against men}

If we talk about men as victims of domestic violence, usually these forms are not physical, but psychological violence, economic or social control. To a certain extent, this albeit unusual, but realistic phenomenon we may ascribe to the level of women's emancipation and its improper perception. In many ways, women want to be self-sufficient, independent and deviate from the perception of women as the gentle sex. They become dominant in the family even in the property or financial relationships and thus they want to decide on the issues in their privacy. For this reason, some forms of domestic violence against men arise. One of the reasons is also the women's interest in revenge against the opposite sex. In most cases, we talk about women who have been victims of a classic stereotypical perception of the role of women in their original family or became victims of violence as children. The rooted hatred of the male sex, which is a psychological problem in this case, leads women to power and dominate manipulation with them. The forms of psychical violence are very insidious and usually motivated by revenge or by interest to harm them - insulting, mockery, underestimating, pointing to the weakness of a man, his low income or inability to secure a family. The pursuit of perfection, the achievement of total harmony or trouble-free functioning leads perfectionists to such psychological, economic or social violence. We encounter physical violence very rarely, because in most cases women 
physically do not exceed men. Similarly, this phenomenon is motivated by the interest of domination in the relationship, the household management or by the interest in revenge on men.

\subsection{Factors of the violence against seniors}

A specific category of victims of domestic violence are seniors. They often overlook the domestic violence even if they suffer from repeated attacks. Some of them are unable to solve this problem because of their physical and mental condition. However, many of them even do not talk about it or do not try to solve this problem out, although it is in their power. They are grateful for every attention, for every expression of interest from the aggressor or they perceive themselves as a burden, so they choose to accept the violence. Last, but not least, they are sometimes afraid of the shame and the feelings of failure in the upbringing of the aggressor. Often the aggressors are the only relatives they have, so they do not want to interrupt their relationships and do not want to solve domestic violence either. The causes of domestic violence against seniors are different - from stress to financial or property causes. On the side of the seniors for risk factors are considered:

- Older age

- Physical disability

- Typical diseases characterized by older age

- Mental illness

- The need for senior care, his or her dependence

- Financially demanding treatment

- Quality property and financial facilities, etc.

Taking care of seniors as well as disabled people is not easy and often requires some professional qualifications or frequent visits of doctors. The aggressor usually has his own family and own world in which he wants and has to work in a certain way, so the care for the senior becomes demanding for him even in financial, time and all other aspects. From the aggressor's point of view the senior becomes a burden that exhausts him and he can not do what he wants (his job, family, interests, etc.), which leads him to the feeling of helplessness, fatigue, often anger and exhaustion. In some cases, there is also a feeling of helplessness in the aggressor if he or she can not secure the care of the senior and from that reason the senior is unknowingly neglected what can harm him or her in different ways. All these feelings - the frustration that is caused by them - is a significant risk factor. It is often the basis, on which certain forms of domestic violence are beginning to emerge. These are usually physical attacks, psychological abuse or neglect of seniors. In a very similar situation are even people with disabilities. It is striking that seniors are becoming victims of domestic violence from property or financial reasons. In this case the aggressor is the child or grandchild of the senior who gains a substantial part of the senior's entire pension in this way. The aggressor is also very often interested in other properties of the senior (usually different real estate or valuable movable property). Violent behavior of children may also be motivated by transcription of the property rights to him or her, or the interest in forcing the seniors to leave their original homes (common house or flat) and to place them in retirement home.

\section{CONCLUSIONS}

Based on the above mentioned, recognizing the causes of domestic violence is a very difficult process. For the reason that the determination of exact causes is not possible, we are therefore interested in and analyzing the factors that can indicate the violent behavior in the family. That is why the contribution in its first section introduces the domestic violence in itself and the difference between the causes and risk factors. Subsequently the contribution deals with the division of risk factors and with these risk factors in different areas against different groups of people. 


\section{Acknowledgement}

The contribution was elaborated as a part of the research project APVV 'Možnosti kriminologického a trestnoprávneho riešenia domáceho násilia' [transl.: Possibilities of Criminological and Criminal Law Solutions of Domestic Violence] No. APVV-15-0644. Head of the project - doc. JUDr. Peter Polák, $\mathrm{PhD}$.

\section{REFERENCES}

Bentovin, A. (1998). Týraní a sexuální zneužívaní v rodinách. Praha: Grada publishing.

Cabanová, V. (2006). Rodina a škola: Kontext rodiny a spoločnosti v čase globalizácie, alebo prečo potrebujeme zachovat' tradičnú rodinu. vol. 54 (2006), 25

Egger, R. (1999). Násilie II - tematické číslo Aspektu : Násilie voči ženám v intímnych vzt’ahoch. Záznam z workshopu, vol. 1(1999), 114

Holcr, K. (2008). Kriminológia. Bratislava: IURA EDITION.

Klimek, L. (2012). New Law on the European Arrest Warrant in the Slovak Republic: Does it Fulfil Standards at the Level of the EU? European Journal of Crime Criminal Law and Criminal Justice, 20(2), $32-37$.

Klimek, L. (2014). The Rule of Speciality as the Right of the Requested Person in the European Arrest Warrant Procedure. In: Piechowiczová, L; Madleňaková, L. (Ed.). (2014). International Multidisciplinary Conference on Autonomy of an Individual (Autonomie jednotlivce), held on September 1921, 2014 in Hrubá Voda. Olomouc: Palacky University in Olomouc, 88-94.

Polák, P., Tittlová, M. (2017). Kriminologické možnosti riešenia domáceho násilia. Bratislava: Wolters Kluwer.

Tittlová, M. (2017). Polák, P., Tittlová, M. Kriminologické možnosti riešenia domáceho násilia: Pojem a znaky domáceho násilia. Bratislava: Wolters Kluwer, 2017.

World Health Organization: World Report on Violence and Health. Geneva, 2002, 98 